\title{
Men in maternity study: A summary of the findings from pre- intervention interviews with women and their husbands attending antenatal clinics at ESIC facilities in Delhi
}

Anurag Mishra

Population Council

Leila Caleb-Varkey

Anjana Das

Emma Ottolenghi

Dale Huntington

See next page for additional authors

Follow this and additional works at: https://knowledgecommons.popcouncil.org/departments_sbsr-rh

Part of the Demography, Population, and Ecology Commons, Family, Life Course, and Society Commons, International Public Health Commons, and the Maternal and Child Health Commons How does access to this work benefit you? Let us know!

\section{Recommended Citation}

Mishra, Anurag, Leila Caleb-Varkey, Anjana Das, Emma Ottolenghi, Dale Huntington, Susan E. Adamchak, and Shahina Begum. 2002. "Men in maternity study: A summary of the findings from pre-intervention interviews with women and their husbands attending antenatal clinics at ESIC facilities in Delhi," FRONTIERS Research Update. New Delhi: Population Council. 


\section{Authors}

Anurag Mishra, Leila Caleb-Varkey, Anjana Das, Emma Ottolenghi, Dale Huntington, Susan E. Adamchak, and Shahina Begum 


\section{FRONTIERS RESEARCH UPDATE}

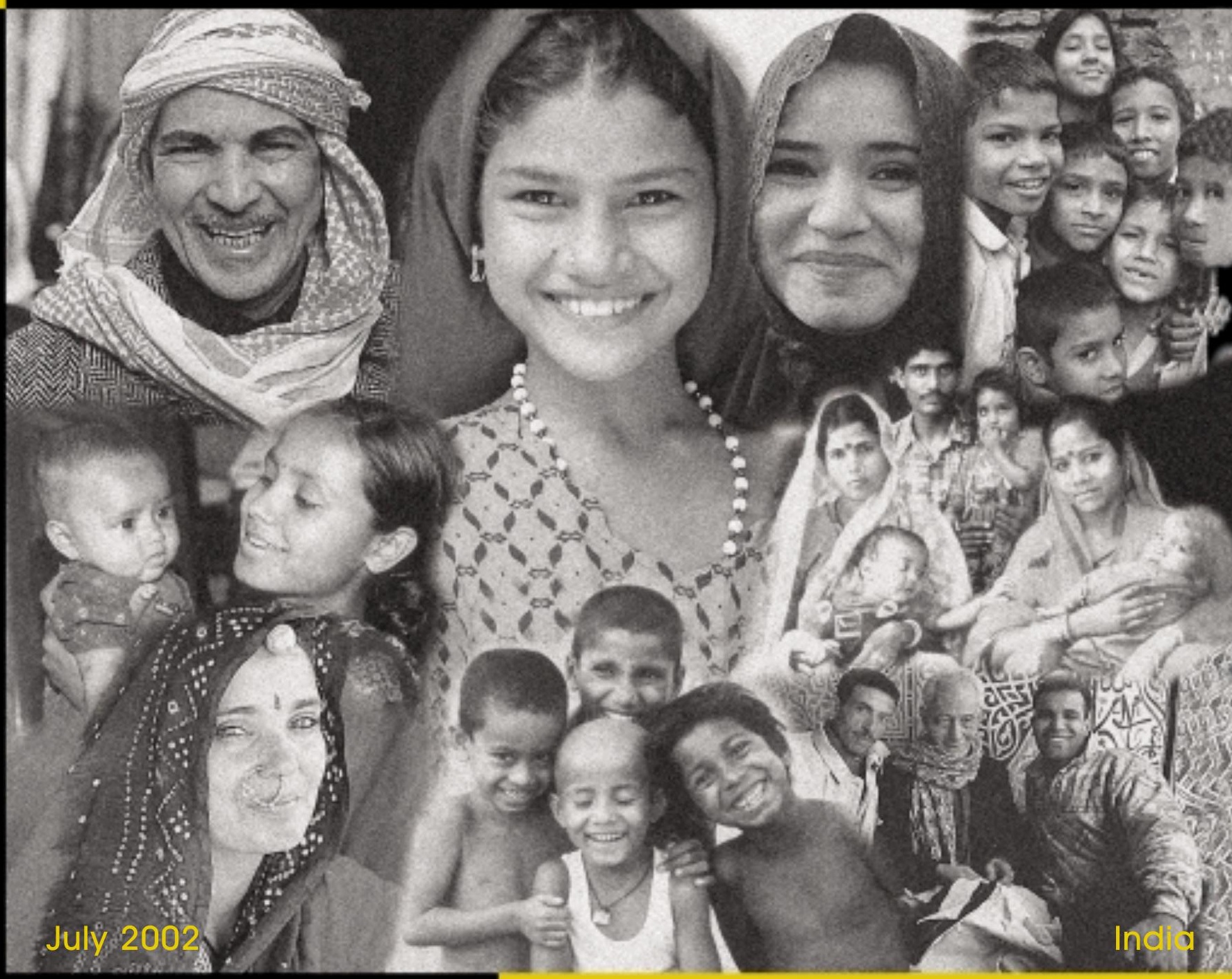

Men in Maternity Study:

A Summary of the Findings from Pre-Intervention Interviews with Women and their Husbands Attending Antenatal Clinics at ESIC Facilities in Delhi 


\section{BACKGROUND}

Most family planning and reproduc tive health programs focus exclusively on women. This environment is often not welc oming or understanding of the needs of men. Men are excluded from matemity care interventions on the premise that they would not be interested or that they would be uncomfortable. The result is that while women receive the bulk of reproductive health education, genderdynamics make men the primary decision-makers. In many sexually transmitted disea ses (STls) more effectively since men are more often symptomatic.

\section{IPOPULATION COUNCIL'S ROLE}

The Frontiers in Reproductive Health program, a USAID funded project of the Population Council is addressing these issues through an operations research (OR) study that investigates the effects of male participation in a new model of matemity care that is gender sensitive and provided at the

The MiM study is underway in six dispensaries across New Delhi operated by the Employees' State Insurance Corporation (ESIC), an a utonomous social security orga niza tion for ind ustrial workers regulated by an Act of Parliament under the Ministry of Labour, Govemment of India. ESIC provides medic al care and insurance to enrolled populations (workers eaming less than Rs. 6,500 per month). In New Delhi, medical services are provided to approximately 2.2 million people through their network of five hospitals, stand-alone emergency facilities, day-care centers and 34 dispensa ries. Young men living in low-income areas of New Delhi account for a major proportion of the caseload at these dispensaries.

settings, men act as gatekeepers to women's access to reproductive health servic es and often hold the decision-making powerover matters such as when and where to seek emergency obstetric care, the place of delivery and use of family planning methods during the postpartum period.

There is a growing awareness and acceptance that men have an important influence on women's health and a lso have distinct reproductive health needs of their own. Reaching out to men as partners may improve spousal communication and may help in early decision-ma king for seeking care if complications arise and may also help define couples sexual and reproductive behavior, goals and perceptions. Servicesfor men can also address primary care level. The immediate objectives are to increase the use of family planning methods in the postpartum period and to promote STl primary preventive practices in men and women. The three year study called Men in Matemity (MiM) is being conducted in South Africa and India. In India, the project is collaborating with the Employees State Insurance Corporation (ESIC). The MiM intervention is facilitating the inclusion of men in their wives' antenatal and postpartum care with couple and individual counseling during pregnancy and at six weeks postpartum. The central elements of the intervention are (a) counseling which focuses on healthy pregnancy behaviors, attention to dangersigns in 
pregnancy and postpartum family planning including LAM and improving knowledge of STls and $\mathrm{HIV}$, their prevention and treatment in cases of male urethritis symptoms and male or female genital ulcers, (b) Universal antenatal Syphilis sc reening and trea tment of both husband and wife in positive cases.

\section{ISTUDY DESIGN}

The OR study uses a quasiexperimental study design to examine the effects of the intervention. Along with the Men in Matemity (MiM) collaborating partners, Population Council staff chose six of the 34 ESIC dispensa ries in Delhi with high antenatal clinic attendance as sites for the study. Three of these were assigned as intervention sites and three as control sites. A sample size of 450 pregnant women was estimated for each site, keeping in mind the key variables and the likelihood of a loss of participants during the follow-up six-month postpartum interview period. All pregnant women attending the ANC during the study period were screened and asked to participate in the study if they met the following criteria:

- They were between 10 and 26 weeks of gestation.

- They were likely to be present in Delhi at the same residential address at six months postpartum.

- They consented to participate in the study/be interviewed and agreed to ask their husbands to be involved (after being fully informed about the study and read the informed consent statement in the questionnaire).

In the control and intervention sites, 486 and 581 pregnant women were interviewed, respectively. Since the intervention involves men in their wives' antenatal and postpartum care, an attempt was made to interview all husbands of the women at the intervention sites after they consented. In 84 percent of the couples, husbands accompanied the women to at least one of her ea rly a ntenatal visits and agreed to participate in the study, the remaining 16 percent may be interviewed at home in the postpartum period if their wife and they agree to be interviewed. A total of 488 husbands were interviewed at the intervention sites. Refusal rates among women were low: 3.6 percent at the control sites and 1.3 percent at the intervention sites.

\section{BASELINE SURVEY FINDINGS}

The data presented in this Update derives from a detailed Preliminary Find ings Report (MEN IN MATERNITY STUDY: Results from the Pre-Intervention Survey of Pregnant Women and their Husbands at the Three Intervention and of only Women at Three Control Employees' State Insurance Corporation

Dispensaries in Delhi, India). Interviews took place in all cases only after consent was first taken from the woman. These interviews were conducted during November 2000 - November 2001. 


\section{General Characteristics}

This section describes the study populations and provides a comparison of individual and household characteristic s of the intervention and control group women in order to establish comparability between the two groups. Table 1 gives a detailed comparison. The interviews with women and men included some basic questions about their socio-demographic characteristics. The results from these questions reveal that women in the control and intervention sites a re similar in terms of most individual and household characteristics. For instance, approxima tely onethird a re illiterate, while 15 percent have more than a high school education in both groups. Most women mentioned that they lived as nuc lea $r$ families while approximately one-third lived with their husband and other relatives. Only a few women mentioned that they usually lived in their ancestral village and not with their husbands in Delhi.

Table 1: General Characteristics of Respondents

\begin{tabular}{|c|c|c|}
\hline \multirow[b]{2}{*}{ Age } & \multicolumn{2}{|c|}{$\begin{array}{l}\text { Proportion of } \\
\text { respondents (Female) }\end{array}$} \\
\hline & $\begin{array}{l}\text { Control } \\
(\mathrm{N}=\mathbf{4 8 6})\end{array}$ & $\begin{array}{l}\text { Intervention } \\
\qquad(\mathbf{N}=\mathbf{5 8 1})\end{array}$ \\
\hline Less than 20 & 7.6 & 7.1 \\
\hline $20-24$ & 53.9 & 48.7 \\
\hline $25-29$ & 29.0 & 34.8 \\
\hline 30 and above & 9.4 & 9.5 \\
\hline \multicolumn{3}{|l|}{ Educ ation } \\
\hline Illiterate & 33.1 & 35.6 \\
\hline Up to 5 years schooling & 3.7 & 4.0 \\
\hline 6 - 10 yea rs schooling & 32.3 & 34.1 \\
\hline More than 10 years & 15.2 & 15.1 \\
\hline \multicolumn{3}{|l|}{ Currently mamied } \\
\hline Yes & 100 & 100 \\
\hline \multicolumn{3}{|l|}{ Total household members } \\
\hline $1-2$ & 17.9 & 17.4 \\
\hline $3-4$ & 54.7 & 48.5 \\
\hline $5-6$ & 16.7 & 23.1 \\
\hline 7 and above & 10.7 & 11.0 \\
\hline
\end{tabular}

\section{Duration of marriage}

$\begin{array}{lll}\text { Less than } 2 \text { years } & 16.5 & 15.0 \\ 2-4 & 29.8 & 26.0 \\ 5-7 & 25.5 & 25.8 \\ 8-10 & 16.5 & 18.2 \\ 11 \text { and above } & 11.7 & 15.0\end{array}$

\begin{tabular}{|lcc|}
\hline & \multicolumn{2}{c}{$\begin{array}{c}\text { Proportion of } \\
\text { respondents (Female) }\end{array}$} \\
\hline No. of living children & $\begin{array}{ccc}\text { Control } \\
\text { (N=486) }\end{array}$ & $\begin{array}{c}\text { Intervention } \\
\text { (N=581) }\end{array}$ \\
\hline None & 37.8 & 32.7 \\
\hline One & 39.3 & 36.0 \\
\hline Two & 16.9 & 22.9 \\
\hline Three & 4.9 & 5.9 \\
\hline Four or more & 1.0 & 2.6 \\
\hline House ownership & & \\
\hline Own house & & 41.7 \\
\hline Privately rented & 39.9 & 55.2 \\
\hline Provided by employer & 56.8 & 3.1 \\
\hline No response & 2.7 & - \\
\hline
\end{tabular}

\begin{tabular}{|lrl}
\hline Number of rooms used for sleeping \\
\hline One & 70.6 & 65.9 \\
\hline Two & 20.2 & 23.1 \\
\hline Three or more & 9.3 & 11.0 \\
\hline Working for money & \\
\hline Yes & 11.5 & 7.7 \\
\hline No & 88.5 & 92.3 \\
\hline
\end{tabular}

\section{Currently living with partner}

\begin{tabular}{lrr}
\hline Only with spouse & 61.5 & 54.9 \\
\hline Living a part from spouse & 0.4 & 0.5 \\
\hline Living with extended family & 38.1 & 44.6
\end{tabular}

\begin{tabular}{lrr}
\hline Only with spouse & 61.5 & 54.9 \\
\hline Living a part from spouse & 0.4 & 0.5 \\
\hline Living with extended family & 38.1 & 44.6
\end{tabular}

Living with extended family $38.1 \quad 44.6$ 


Women tend to be less educated
than their husbands, younger in
age by approximately five years
and less likely to be working
outside the home. In most cases,
men stayed home at night but 12
percent of women reported that
their husbands were a way at
night at least one week per
month.
Pregnancy History and
Desire for Another Child
This cohort of women was
generally young and of low
parity, howevera sizable
proportion mentioned having had
a pregnancy loss (10 percent)
either through miscarriage or
medical termination of
pregnancy (MTP).

desirable since they did not have any child ren or only one child. Half of the women with two or more living children, however, reported that they would have liked to postpone this pregnancy or not have a ny more children.

The following sections present data formen and women only from the Intervention Sites on key reproduc tive health issues such as family planning, matemity and child care, spousal communication and support, and on sexually transmitted infections (STls).

\section{Family Planning}

This section provides a summary of information on men's and women's knowledge of the fertile period, family planning use and
The average

duration of marriage for couples was 6.3 years and the mean number of living children for the control group was 0.92 and 1.10 for the intervention group. The median age of the youngest child was around two years. For 23 percent of the women from the intervention group and 29 percent of the control group this was their first pregnancy. Most women reported that this pregnancy was

\section{Figure 1: Desire for Cument Pregnancy}

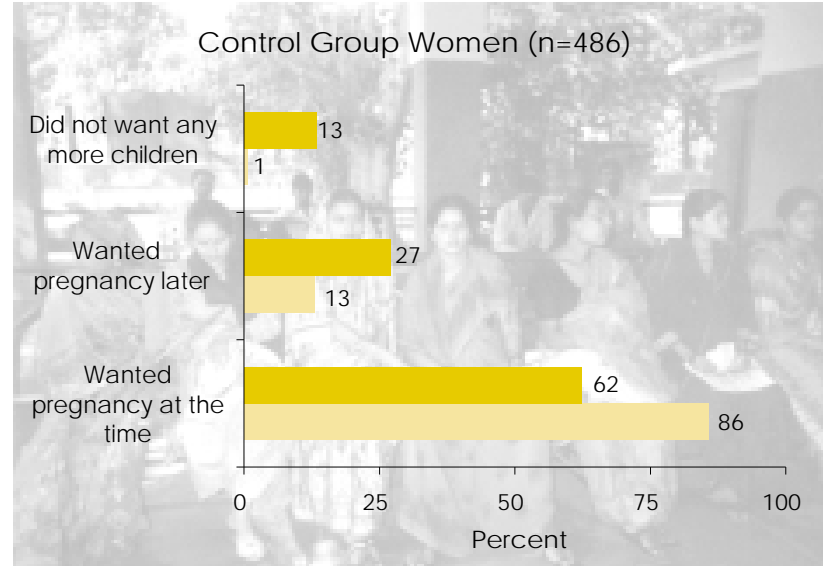

Women with no child $\square$ Women with any children

Intervention Group Women $(n=581)$

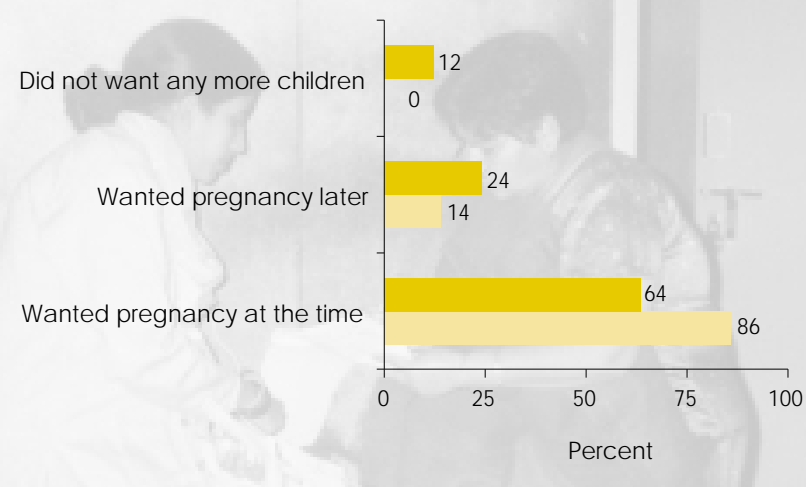


desire for child ren after this pregnancy.

The survey asked whether respondents had ever used any family planning method in the past and the method used. Twenty five percent of women reported that they had used a method and 64 percent revealed they intended using a method in the future. A much higher proportion (40 percent) of men reported having ever used a family planning method and a lower proportion (56 percent)

\section{Figure 2: Postpartum Family Planning Intention among Respondents with at least One Child}

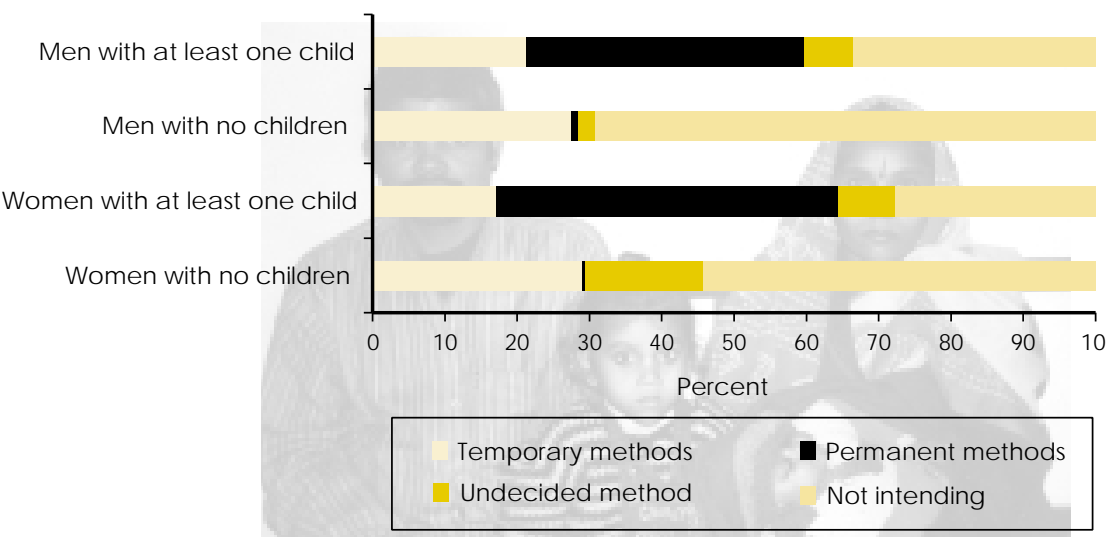

Table 2: Family Planning Knowledge, Use and Intention to Use a Method in the Future

\begin{tabular}{|c|c|c|}
\hline Family planning knowledge & $\begin{array}{l}\text { Women with } \\
\text { no child } \\
(\mathrm{N}=190)\end{array}$ & $\begin{array}{l}\text { Women with } \\
\text { at least one } \\
\text { child } \\
(\mathrm{N}=391)\end{array}$ \\
\hline $\begin{array}{l}\text { Know fertile days of menstrual } \\
\text { cycle correctly }\end{array}$ & 2.8 & 10.8 \\
\hline $\begin{array}{l}\text { Knowledge of Lactational } \\
\text { Amenornoea Method }\end{array}$ & 0.0 & 0.0 \\
\hline $\begin{array}{l}\text { Ever used a fa mily planning } \\
\text { method }\end{array}$ & 11.1 & 31.7 \\
\hline $\begin{array}{l}\text { Using a family planning method } \\
\text { at the time of conception }\end{array}$ & 0.2 & 5.9 \\
\hline Wanted pregnancy at current time & 85.9 & 63.5 \\
\hline \multicolumn{3}{|l|}{ Future intentions } \\
\hline Want a nother child a fter this child & 91.6 & 24.6 \\
\hline $\begin{array}{l}\text { Intend to use a family planning } \\
\text { method in the future }\end{array}$ & 45.8 & 72.4 \\
\hline $\begin{array}{l}\text { Intend to use a spacing method in } \\
\text { the future }\end{array}$ & 28.9 & 17.1 \\
\hline Total number of women & 190 & 391 \\
\hline
\end{tabular}

reported that they intended using a method in the future.

Female sterilization was the favored family planning method. Forty three percent women with at least one child reported that they planned to undergo a female sterilization procedure while 4lpercent of men reported female sterilization as their preferred method. Intention to use a family planning method varied by parity a mong women as demonstrated in Table 2 . The most often mentioned source of method was the ESIC facility followed by a private provider. Men mentioned more family planning use than women, reporting higher condom use and oral pill use. A third of women with at least one child reported having used a family planning method in the past and 11 percent of nulliparous women also reported having used a method in the past.

An a nalysis of family planning use and intentions demonstrated that among the first time pregnant women, most women wanted the pregnancy at the time, however in those with at least one other child, 24 percent would have wanted to delay the pregnancy and at least 13 percent stated that they had not wanted any more children. However their perceptions and desire of this pregnancy did not necessa rily match their use of family planning method in the past. Only a few women with no child reported using a method of contraception at the time they became pregnant while 5.9 percent with at least one child 


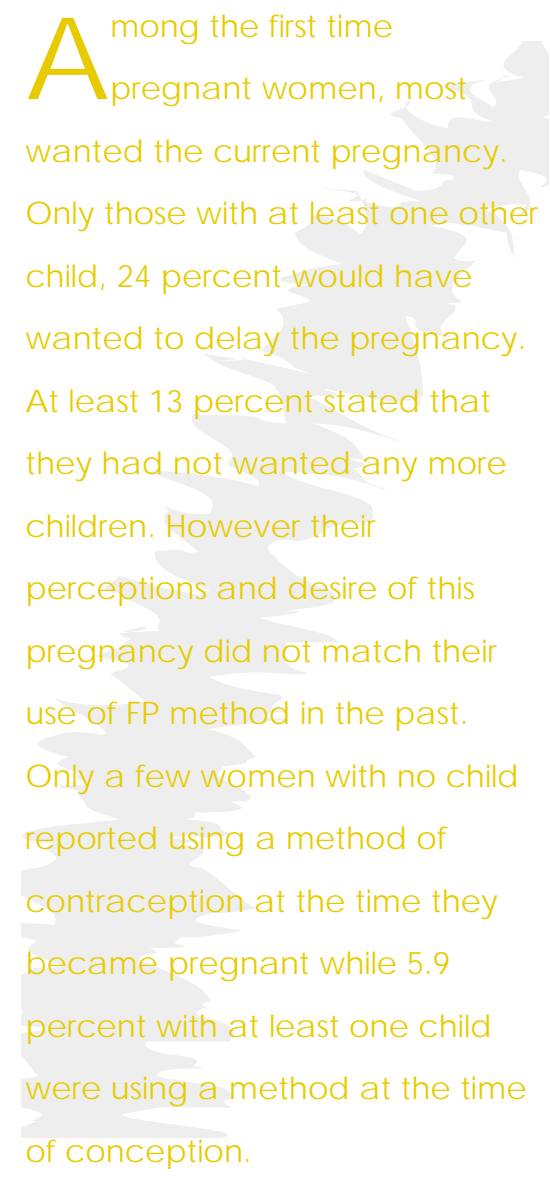

of conception. were using a method at the time of conception.

Among those who had used contraception, 15 percent revealed that they were using a method when they became pregnant, suggesting that counseling on correct and consistent use of a family planning method needs to be add ressed.

A review of the family planning data reveals that the most frequently mentioned pattem is to not use a ny family planning method before the second birth, followed by a desire for female sterilization. This is however prevalent once the couple has had at least one son. The survey did find exceptions: 28 percent of nullipa rous women and 17 percent of women with at least one child intend to use a spacing method a fter this child. This high unmet need is also reflected from the fact that although women tend to state that they desire spacing, information on age of the last child shows that in 25 percent of cases birth would occurbefore the previous child was even 24 months old.

\section{Maternity and Child Care}

This section provides a brief summary of information collected about women's and men's knowledge of matemity care, breastfeeding and childhood immunization. Table 3 summa nizes the results from the baseline survey related to spousal communication on matemity care and couples' knowledge and intentions about matemity and childcare.
Of the women who had children, 95 percent said that her youngest child had received any immunization. In a third of the cases, the husband was responsible for taking the child or accompanying his wife to the clinic for this visit. Intention to breastfeed is universal, but 15 percent women felt that this may not be exclusive and seven percent women were undecided. Antenatal care was seen as a time to assess matemal and fetal health and potential problems. Most women reported that the ir husbands encouraged them to attend these services and they felt welcomed at the clinic.

\section{Spousal Support during Pregnancy and Inter- spousal Communication}

It is hypothesized that male participation in matemity care will result in greater communic ation between men and women on subjects related to reproduc tive health and child care. The baseline survey included questions about couple communic ation and desire for involvement of husbands in reproductive health care.

Women expect husbands to share in household tasks when pregnant, especially lifting heavy objects. Both men and women feel that men should accompany them to antenatal visits and women would like them present in the room during consultations and during discussions on matemity care and family planning. A large number of couples have disc ussed health and childcare during this pregnancy but few mentioned discussing STls. 
Table 3. Spousal Communic ation and Support during Matemity and Child Care

\begin{tabular}{lcc}
$\begin{array}{l}\text { Matemity and Child Care: Spousal } \\
\text { Support and Communic ation }\end{array}$ & $\begin{array}{c}\text { Women } \\
(\mathbf{N}=\mathbf{5 8 1})\end{array}$ & $\begin{array}{c}\text { Men } \\
(\mathbf{N}=\mathbf{4 8 8})\end{array}$ \\
$\begin{array}{l}\text { Desire husband's involvement } \\
\text { Accompany wife to ANC clinic and wait }\end{array}$ & 97.4 & 98.2 \\
$\begin{array}{l}\text { Be in the room during examination } \\
\begin{array}{l}\text { Be in the room during family planning } \\
\text { consultations }\end{array}\end{array}$ & 64.4 & 77.7 \\
\hline
\end{tabular}

\section{Disc ussed these topics with spouse during pregnancy:}

Matemity care

79.5

80.1

New baby's health

36.5

74.6

Sexually transmitted infections

8.1

30.3

Family planning

48.0

44.7

\section{Antenatal care services:}

Report knowing any signs of

10.3

21.1

complic ations in pregnancy

Report husband encouraged them to

77.6 attend antenatal clinic

\section{Reason for attending the antenatal clinic:}

To find out the pregnancy is nomal

$55.9 \quad 62.7$

To find out if there are any problems

47.8

59.8

To get vaccinations

31.8

19.7

To get vita mins/iron

24.6

18.9

\section{Feel men are welcome at the ANC/PNC clinic:}

$\begin{array}{lrr}\text { Yes } & 93.1 & 84.8 \\ \text { No } & 0.0 & 11.9 \\ \text { Don't know } & 6.9 & 3.3\end{array}$

\section{Spousal support Desired physical help during pregnancy, frequently mentioned responses:}

\begin{tabular}{lrr} 
Household chores & 64.7 & 60.0 \\
Camy heavy loads & 18.6 & 27.3 \\
Look after children & 8.8 & 1.0 \\
Breastfeeding: & & \\
Intend to breastfeed exclusively & 77.6 & 83.6 \\
\hline $\begin{array}{l}\text { Immunization: Child accompanied by: } \\
\text { Mother }\end{array}$ & 10.5 & 17.5 \\
Father & 28.6 & 28.3
\end{tabular}

Most men and women are una ware of any life threatening or serious c onditions during pregnancy that they should be alert for and seek medical attention. Prompt recognition and immediate care seeking in the face of a danger sign are considered among the most important life-saving behaviors in pregnant and immediate postpartum women.

Spontaneous multiple answers to questions on knowledge of life threa tening problems during pregnancy and child birth documented the number of men and women mentioning one of the following: fever, bleeding, swelling of hands and face, high blood pressure, prolonged labor and premature rupture of membranes. Both men and women knew very few of these conditions

Fifty two percent of women mentioned that they have disc ussed what to do in the event of an emergency and she is required to be taken to the hospital. All the women reported that her husband would assist her to get to the hospital in case of any emergency or any danger signs of pregnancy. More than threefo urths of the women said they disc ussed matemity care and plan for birth with their husbands. About half of the women said they discussed family planning.

\section{Sexually Transmitted Infections}

This section provides information on knowledge, perceptions and 
reported symptoms suggestive of stls among men and women interviewed. Both men and women were asked if they knew about HIV/AIDS and STls and if they had experienced any symptoms themselves. Key results are reported in Table 4.

The percentage of women and men a wa re of HIV/AIDS is higher than the percentage aware of

Table 4: Knowledge, Perception and Reported Symptoms of STls among Women and Men

\begin{tabular}{|lcc|} 
& $\begin{array}{c}\text { Women } \\
(\mathbf{N}=581)\end{array}$ & $\begin{array}{c}\text { Men } \\
(\mathbf{N}=\mathbf{4 8 8})\end{array}$ \\
\hline Ever heard of STIS & 29.8 & 68.9 \\
Ever heard of HIV/AIDS & 48.5 & 93.4
\end{tabular}

\section{Knowledge of protection from STls or HIV/AIDS}

Stay faithful to your husband/wife

53.7

25.7

Use condoms

Avoid sharing razors and needles

45.2 35.8

\section{Knowledge about condoms and dual protection}

Prevent or protect from pregnancy

$54.9 \quad 25.0$

Prevent or protect from ST/HIV/AIDS

0.3

Prevent both ST/HIV/AIDS and pregnancy

23.6

69.5

\section{Perceived risk of ac quiring an STI or HIV/AIDS}

$\begin{array}{lrr}\text { No chance } & 33.9 & 92.4 \\ \text { Some chance } & 5.7 & 1.8 \\ \text { High chance } & 0.3 & 0.0 \\ \text { Already infected } & 0.5 & 0.0\end{array}$

\section{Reported symptoms suggestive of STls in the past six months}

Husband had pain / buming unination

$1.4 \quad 9.2$

and urethral discharge

Self-report of genital sore or ulcer

1.2

\section{Treatment seeking}

Any trea tment or advice sought

100.0

64.4

(multiple response)

ESIC provider

37.5

Private doctor

75.0

\section{Among those who sought treatment}

Stopped having sex during trea tment

$12.5 \quad 65.5$

Used condom

37.5

$(\mathbf{N}=7)$

$(\mathrm{N}=\mathbf{2 9})$ 
STls. About 30 percent of women and 69 percent of men have heard of STls or "hidden illness" as litera lly translated from the Hindi term, whereas about half of the women and 93 percent of men have heard of the disea se called HIV/AIDS, which means that approximately twice as many men than women have heard of these diseases.

In order to understand whether respondents are awa re of symptoms of STls, they were asked if they knew any symptom of STls in men and women, separately. Signific a ntly only about one-fifth of men and one percent of women could mention any symptoms of STls in men (78.5 percent of men and 99 percent of women said they did not know any symptoms of STls in men).

Only 3.3 percent men said that pa in or buming with unination, 2.5 percent said that genital discharge and 3.7 percent said that sores or ulcers were ma nifestations of STls in men.

When asked specific ally, what the pain or buming sensation occuring during urination meant, more than half of the men (51 percent) stated that it indicated an STl or a health problem that needed medical consultation. Among women eight percent identified them as symptoms of disease. When a sked the significance of a genital sore or ulcer in a man or a woman, 57 percent of men identified it as a disease and 37 percent stated they did not know any significance. To the same question, only 2.2 percent of women stated that a genital sore or ulcer indic ated a disease and 89 percent did not know the significance.

The perception of risk for acquiring an STl and/or HIV/AIDS was low among men and women. Ninety two percent of men and 34 percent of women clearly mentioned they had no chance of being infected. However, about 60 percent of women did not know about their chances of contracting infections. Only a bout eight percent women mentioned having disc ussed STls and HIV/AIDS with their husbands.

\section{Condoms and Dual Protection}

Condoms are more likely to be viewed as a contraceptive method than a bamieragainst STls, however many men and women are aware of the dual protection value that condoms offer in the prevention against STls including HIV/AIDS. Less than two percent of the men and women reported symptoms of genital sores or ulcer in the past six months.

In the cases of reported genital ulcers all the women and half of the symptomatic men reported treatment. Among men with symptoms of urethral disc harge, one-third of the men did not report seeking any treatment and 44 percent reported using condoms or abstaining while on treatment.

\section{SUMMARY}

- Data revealed that the number of MTPs/elective abortions increased with parity, indicating an unmet need for family planning in the ESIC population.

- Other strong indic ators of unmet need included a birth interval of less than 24 months in 25 percent of the women who had a living child, despite a stated desired by 42 percent of the women for delaying or preventing the current pregnancy.

- Of the women who preferred to wait at least two years before having another child, 44 percent stated they intend to use a family planning method. Of those women who did not want more children, only 68 percent stated they intended to use a family planning method.

- Almost all women and men stated that they would like to attend ANC services jo intly. Two-third of the women wished to have the husbands present during the physical exam and labor and birthing, as did three-fourth of the men. This is a surprisingly high proportion given traditionally held perceptions on gender roles and the current situation where men accompanied their wives but did not participate in antenatal and postpartum services.

- Reproductive health knowledge, including fertility cycle, danger signs in pregnancy, importance of exclusive breastfeeding, LAM, and HIV/AIDS was uniformly low in the population represented by the interviewed men and women. 


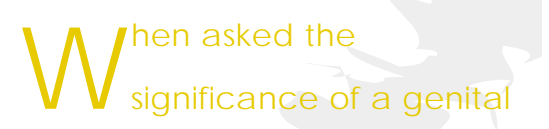

sore or ulcer in a man or a woman, 57 percent of men

identified it as a disease and 37 percent stated they did not know any significance. To the same question, only 2.2 percent of women stated that a genital sore or ulcer indic ated a disea se and 89 percent did not know the significance.
However, in all cases, men appeared to know more than their spouses, even about women's reproductive health.

- Although most men had heard of HIV/AIDS, most women had not, and both genders possessed low specific knowledge of this disease. ST knowledge was even lower, particularly men's knowledge of urethral disc harge symptoms as indic a tive of an STI. Women had extremely limited knowledge of any STls and their symptoms.

- Women and to a lesser extent men, had very low knowledge of danger signs in pregnancy, birth and immediate postpartum.

These differences may be attributed to husbands' higher educational level and exposure to media/IEC by virtue of their working outside the home.

\section{CONCLUSIONS}

The results of the baseline survey suggest that the women from the control and intervention groups share almost similar individual and background characteristics. A general comparison of male and female data on the same question suggests that men are more likely to give a positive response than women, as frequencies for all variables with a yes-no response show higher proportions of men responding yes.

Results reinforce the evidence from the literature that the Men in
Matemity interventions a re a ddressing issues that a re locally relevant. For example, the survey suggests that both men and women would like their husbands to be involved in matemity care; that there is an unmet need for postpa rtum fa mily planning methods; and that more information on sexually transmitted infections and HIV/AIDS is vita lly needed.

Besides these differences in levels of knowledge and perceptions on most issues between men and women suggests that communic ation on all these reproductive health issues between spouses should be encouraged.

The success of the MiM intervention in meeting the need for reproductive health information and communication to change behaviors on these c ritical issues will be a ssessed through a survey of the same population six months after the birth of the child. 


\section{Population Council}

The Population Council is an intemational nonprofit, nongovemmental institution that seeks to improve the wellbeing and reproductive health of c urrent and future generations a round the world and to help achieve a humane, equitable, and sustainable balance between people and resources. The Council conducts biomedic al, social science, and public health research and helps build research capacities in developing countries. Established in 1952, the Council is govemed by an intemational board of trustees.

This public ation was made possible through support provided by the Office of Population, Health and Nutrition of the UNITED STATES AG ENCY FOR INTERNATIO NAL DEVELOPMENT (USAID), under the terms of Cooperative Agreement Number HRN-A-00-98-00012-00. The opinions expressed herein are those of the author and do not necessarily reflect the views of USAID.

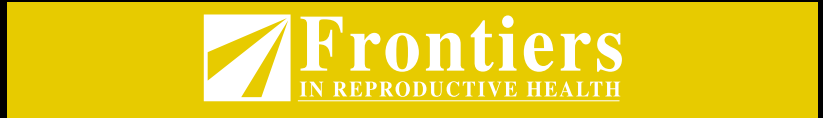

Men in Matemity Study: A Summary of the Findings from Pre-Intervention Interviews with Women and their Husbands Attending Antenatal Clinics at ESIC Facilities in Delhi, Research Update, J uly 2002, New Delhi.

- CONTRIBUTORS:

Anurag Mishra, M.P.S., M.Sc . Leila Caleb Varkey, Sc.D. Anjana Das, M.B.B.S., D.C.H. Emma Ottolenghi, M.D. Da le Huntington, Sc.D. Susan Ada mchak, PhD. Shahina Begum, M.P.S., M.Sc .

- EDIING, VISUALSATION AND DESIGN: Sohini Roychowdhury, PGDPR

- ACKNOWLEDGEMENT:

Chris Parker, M.A.*

*(Not Population Council staff)

- PRODUCED AND PRINTED BY: macro graphics.comm pvt. Itd., New Delhi
INDIA

53 Lodi Estate

3rd Floor

New Delhi 110003

Tel: $91-11-461-0913 / 4$

Fax: $91-11-461-0912$

E-mail: frontiers@pcindia.org
- WASHINGTON

4301 Connecticut., N.W.

Suite\#280

Washington, D.C. 20008

Tel: 1-202-2379400

Fax: 1-202-237 8410

E-mail: frontiers@pcolc.org 